\title{
Correction to: Some thoughts and greetings from the new Editor-in-Chief
}

\author{
Antonio Barile ${ }^{1}$
}

Published online: 24 September 2021

(C) Italian Society of Medical Radiology 2021

\section{Correction to: La radiologia medica https://doi.org/10.1007/s11547-020-01324-6}

The article Some thoughts and greetings from the new Editor-in-Chief, written by Antonio Barile, was originally published online on 27 January 2021 with Open Access. This article is licensed under a Creative Commons Attribution 4.0 International License, which permits use, sharing, adaptation, distribution and reproduction in any medium or format, as long as you give appropriate credit to the original author(s) and the source, provide a link to the Creative Commons licence, and indicate if changes were made. The images or other third party material in this article are included in the article's Creative Commons licence, unless indicated otherwise in a credit line to the material. If material is not included in the article's Creative Commons licence and your intended use is not permitted by statutory regulation or exceeds the permitted use, you will need to obtain permission directly from the copyright holder. To view a copy of this licence, visit http://creativecommons.org/licen ses/by/4.0/.

After publication in volume 126, issue 1, pages 3-4 the author(s) decided to cancel the Open Access. Therefore, the copyright of the article has been changed on 18 February 2021 to OItalian Society of Medical Radiology 2021 with all rights reserved.

Publisher's Note Springer Nature remains neutral with regard to jurisdictional claims in published maps and institutional affiliations.

The original article can be found online at https://doi.org/10.1007/ s11547-020-01324-6.

Antonio Barile

antonio.barile@univaq.it

1 Department of Biotechnology and Applied Clinical Sciences, University of L'Aquila, L'Aquila 67100, Italy 